INTERNATIONAL JOURNAL
OHARMACEUTICAL SCIENCES
PESEARCH
RESEM

Received on 30 July, 2017; received in revised form, 30 October, 2017; accepted, 27 January, 2018; published 01 May, 2018

\title{
CHARACTERIZATION AND STABILITY OF EXTRACELLULAR ALKALINE PROTEASES FROM HALOPHILIC AND ALKALIPHILIC BACTERIA ISOLATED FROM SALINE HABITAT OF LONAR SODA LAKE, INDIA
}

\author{
Vijayshree M. Hemke ${ }^{1}$ and Vishal R. Dhundale ${ }^{* 2}$ \\ Jijamata Mahavidyalay ${ }^{1}$, Buldhana - 443203, Maharashtra, India. \\ New Arts Commerce and Science College ${ }^{2}$, Ahmednagar - 414001, Maharashtra, India.
}

Keywords:

Bacillus, Extremozymes,

Protease, Metalloenzyme

\section{Correspondence to Author:}

Vishal R. Dhundale

Department of Microbiology,

New Arts Commerce and

Science College, Ahmednagar -

414001, Maharashtra. India.

E-mail: vrdvishal@gmail.com

\begin{abstract}
Culture dependent phenotypic characterization analyses were applied to study the protease producing bacteria from Indian Soda (Lonar crater). The uniqueness of the Lonar lake water is its salinity and alkalinity. A total of one hundred and fourteen bacterial cultures were isolated from the water and sediment samples collected from the hyper alkaline saline environment of Lonar lake. The thirty two bacterial strains were found protease producing bacterial culture, out of them strain EW2 was selected for 16S rDNA sequencing, production and partial characterizations of protease on the basis of their maximum proteolytic activity. The phylogenetic position indicated the strain was related to phylum Firmicutes. Optimum enzyme activity was found to be at $80{ }^{\circ} \mathrm{C}$ and $\mathrm{pH} 9.5$. The protease was highly stable over broad temperature from 40 to $90{ }^{\circ} \mathrm{C}, \mathrm{pH} 7.0-12.0$, showing excellent thermostablity and alkaline tolerant nature. The enzyme activity has enhanced by all metal ion which was tested in this studies indicating it was a metalloenzyme but inhibited by organic solvent except acetone. This is valuable information for enzyme production and optimization of protease from Bacillus pumilus EW2 has bright future towards the improvement and production of novel enzymes for leather, detergent and pharmaceuticals industries and biotechnological potential.
\end{abstract}

INTRODUCTION: The extracellular enzymes are secreted by wild group of organism comprise fungi bacteria, yeast actinomycetes ${ }^{1}$. Alkaliphilic microorganisms, in particular Bacillus species, have attracted much interest because of their ability to produce extracellular metabolites that are active and stable at high $\mathrm{pH}$. The unusual properties of these metabolites offer a potential opportunity for their utilization in processes demanding such extreme conditions ${ }^{2}$.

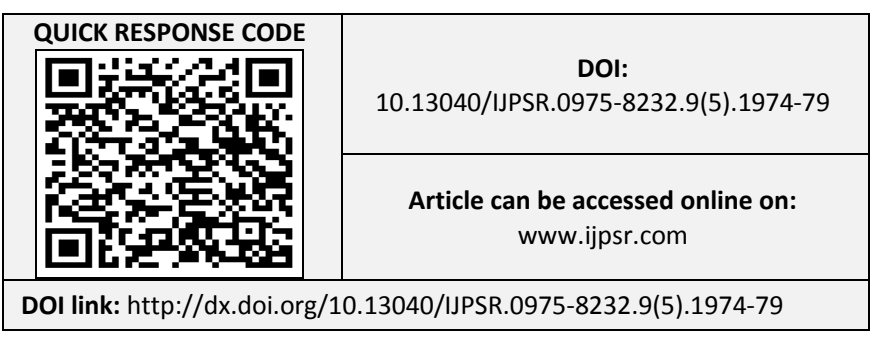

The reason for this is their high $\mathrm{pH}$ exibiting range of $\mathrm{pH} 6-12$ and temperature stability. Alkaline proteases belong to the group of serine proteases, or metalloenzyme ${ }^{3}$. Those from Bacillus species have wide use and importance in several industrial economies such as in food, detergent and in the synthesis of biologically active peptides ${ }^{4}$. Extremozymes have a great biotechnological potential, including agricultural, chemical and pharmaceutical applications 5,6 .

Due to the harsh condition in industrial production process, the present enzymes are not sufficient to meet most of the potential, so in last decades isolation and characterization of extremophiles have attracted attention ${ }^{7}$. Halalkalophiles are saltloving organisms survive in alkaline environment that inhabit hyper-saline alkaline environments. 
They are characterized by large amounts of $\mathrm{NaCl}$ saturation due to the evaporative concentration. The progression and formation of alkalinity and salts also concentrate, giving rise to an alkaline saline environment ${ }^{8}$. Such type of condition generated in the soda lakes. Soda lakes are the most stable alkaline environments in the world, with $\mathrm{pH}$ values generally higher than $10-12^{9}$.

The bacteria survive in the soda lakes are mostly alkaliphilic, it is to be considered that extracellular enzymes synthesized by alkaliphilic bacteria would be diligent under alkaline stipulations. These extremozymes are active in absence or presence of trace amount of some metal ions and such enzymes are of biotechnological potential ${ }^{6}$. The Lonar lake is the great soda lake which is located in Lonar, District Buldhana, Maharashtra, India (latitude $19^{\circ}$ 8 , longitude $76^{\circ} 36$ ).

The alkaline Lonar crater is a unique basaltic rock meteorite impact crater, ranking third in the world and is filled with saline water having an average $\mathrm{pH}$ of 9.5 - 10. The Lonar lake was extensively studied for their bacterial diversity based on traditional and modern techniques with potential applications ${ }^{10-13}$. In view of the above facts, the present study focused on the screening and characterization of extracellular protease production from Bacillus pumilus.

\section{MATERIALS AND METHODS:}

Enrichment and Isolation of Microorganisms: Lonar lake water and sediment sample were collected in sterile bottles and polythene bags respectively, from defined sampling site. Enrichment of water samples and sediment samples were carried out in Horikoshi I, Horikoshi II and nutrient agar at $\mathrm{pH} 10$, nutrient agar at $\mathrm{pH} 10.0$ with 30 g 1 - 1 sodium chloride. All flasks were incubated at $37^{\circ} \mathrm{C}$ on a rotary shaker $(100 \mathrm{rpm})$ for 48 h. After enrichment, well isolated and morphologically distinct colonies from these plates were transferred on the respective medium slants.

Screening of Bacterial Alkaliphiles: Individual bacterial colonies were screened for proteolytic activities on Skim milk agar medium. The inoculated plates were incubated at $37{ }^{\circ} \mathrm{C}$ for $48 \mathrm{hrs}$ and observed for zones of clearance, represents proteolytic activities ${ }^{14,15}$.
Identification of the Proteolytic Isolates: These isolates were identified in accordance with the methods recommended in Bergey's manual of determinative bacteriology and diagnostic microbiology. The identified strains were maintained on nutrient agar slants having $\mathrm{pH} 10$ at $4{ }^{\circ} \mathrm{C}$.

16S rDNA Sequences and Phylogenetic Analysis: DNA was extracted from bacilli culture using standard phenol chloroform protocol ${ }^{16}$. The partial sequence of the 16S rRNA gene was amplified by using polymerase chain reaction and universal primer Eubacteria specific primers, 16F 27 (5' CCAGAATTGATCMTGGCTCAG- 3') and 16R 1525 (5' TTCTGCAGTCTAGAAGGAGGTGWT CCAGCC- 3'). The amplified 16S rRNA gene PCR products from these isolates were directly sequenced after purification by precipitation with polyethylene glycol and $\mathrm{NaCl}$ procedure ${ }^{17}$.

Preparation of Crude Enzyme Extracts: The 100 $\mathrm{ml}$ Casein nutrient broth (casein $1 \mathrm{gm}$, peptone 0.5 gm, yeast extract $0.15 \mathrm{gm}$, beef extract $0.15 \mathrm{gm}$, sodium chloride $0.5 \mathrm{gm}, \mathrm{pH} 10$ ) was prepared. The sterile broth was inoculated with culture and incubated for $48 \mathrm{hrs}$ at $37{ }^{\circ} \mathrm{C}$. After $48 \mathrm{hrs}$ incubation, centrifugation of the broth at $5000 \mathrm{rpm}$ for 15 min was carried out ${ }^{18}$.

Enzyme Assay: The standard graph of tyrosine was prepared by adding different concentration of standard tyrosine $(1 \mathrm{mg} / \mathrm{ml})$. Estimation of proteases was carried out with $2.5 \mathrm{ml}$ of casein in a test tube; $1 \mathrm{ml}$ of enzyme source was added and incubated for $10 \mathrm{~min}$ at room temperature. After incubation $2 \mathrm{ml}$ of TCA was added to stop the reaction and centrifuged the reaction mixture at 5000-8000 rpm for $15 \mathrm{~min}^{19}$.

Partial Characterization of Protease: Partial characterization of protease from Bacillus was carried out by effect of $\mathrm{pH}$, temperature, substrate, enzyme, metal ions and organic solvents on alkaline protease activity were then measured as per assay procedure.

Effect of Different Metal Ions on Protease Activity: The effect of different metal ions on alkaline protease activity was determined. The enzyme assay was performed in the reaction mixture as described above in the presence of various metal ions at a final concentration of $1 \mathrm{mM}$. 
The activity of the enzyme without any additives was taken as $100 \%$. The influence of various metal ions $(1 \mathrm{mM}$ each) on protease activity was studied by pre-incubating the enzyme with the compounds for $15 \mathrm{~min}$ at $37{ }^{\circ} \mathrm{C}$. Then, the remaining activity was measured under the enzyme assay conditions.

Enzyme Stability in Presence of Solvents: Stability of the protease enzyme was determined in the presence of various organic solvents $(10 \mathrm{mM}$ each). $0.25 \mathrm{ml}$ of organic solvent was added to $1 \mathrm{ml}$ of the protease solution in a $1.5 \mathrm{ml}$ micro centrifuge tube with a screw cap. The mixture was shaken at $150 \mathrm{rpm}$ for $100 \mathrm{~min}$ at $37^{\circ} \mathrm{C}$. Then, the remaining activity was measured under the enzyme assay conditions.

\section{RESULTS AND DISCUSSION:}

TABLE 1: MORPHOLOGICAL AND BIOCHEMICAL CHARACTERS OF BACILLUS SP. EW - 2

\begin{tabular}{ccc}
\hline S. no. & Test & Observation \\
\hline 1 & Isolation Media & E \\
2 & Color & White \\
3 & Shape of Colony & Circular \\
4 & Size of Colony & $1 \mathrm{~mm}$ \\
5 & Elevation & Convex \\
6 & Edge & Entire \\
7 & Gram Reaction & Positive \\
8 & Shape & Short rod \\
9 & Spore Reaction & + \\
10 & Motility & + \\
11 & Catalase & + \\
12 & Oxidase & + \\
13 & Glucose & + \\
14 & Arabinose & + \\
15 & Mannitol & - \\
16 & Xylose & + \\
17 & Sucrose & - \\
18 & Maltose & - \\
19 & Fructose & + \\
\hline
\end{tabular}

Screening of Bacterial Isolates, Identifications and Characterization of Bacterial Cultures: There is very less studies were performed on the about the microbial diversity of hyper-saline alkaline Lonar crater especially from sediment and water characterized by alkaline and saline conditions. Bacillus EW-2, isolated from those microsites, shares with other alkaliphilic Bacillus species the capacity to grow at high $\mathrm{pH}$ values ${ }^{20,21}$. During a previous study carried out from 2008 to 2017, total one hundred and fourteen alkaliphilic bacterial cultures were isolated from Lonar lake ${ }^{13,22}$. In the present study, out of one hundred and fourteen, thirty two bacterial cultures were found with proteolytic activity. All the bacterial strains were found alkaliphilic. According to Bergey's manual of systematic bacteriology, the isolates were identified as Bacillus sp. All the bacterial cultures were found gram positive and spore forming bacilli. Out of these thirty two, one bacterial isolate was selected for the further production and characterizations on the basis of their maximum proteolytic activity of Bacillus sp. EW-2. In the present studies the 16S rDNA analysis of isolates EW2 indicated that the bacterium affiliated to Firmicutes, which included family of bacilliace, belong to Bacillus pumilus EW2.

Effect of pH on Activity of Enzyme Protease: The effect of $\mathrm{pH}$ on protease activity of Bacillus pumilus EW-2 was determined by incubating the enzyme in different $\mathrm{pH}$ buffers ranging from $7-12$ for 10 minutes at $37^{\circ} \mathrm{C}$. The enzyme was stable over the $\mathrm{pH}$ range of $7-12$. The protease was active in a wide $\mathrm{pH}$ range with optimum activity at $\mathrm{pH} 9.5$ and was stable over a broad $\mathrm{pH}$ range $7-12$ with retention of more than $58-73 \%$ of initial activity. The optimum activities of this enzyme were at $\mathrm{pH} 9.5$ with 35 units $/ \mathrm{mL}$. The enzyme activity decreased dramatically at $\mathrm{pH} 10(70 \%)$ and $12(58 \%)$. The optimum $\mathrm{pH}$ range of alkaline proteases is between $\mathrm{pH} 9$ and $11^{23}$. Alkaline protease from Bacillus EW-2 novel feature in the extremozyme which can produce the protease at alkaline $\mathrm{pH}$ which was beneficial for biotechnological potential and industrial application.

The similar studies were performed by Sookkheo et al., ${ }^{24}$ reported from thermophilic Bacillus stearothermophilus TLS33, optimum $\mathrm{pH}$ values of 8.5.To determine the optimum $\mathrm{pH}$ for enzyme activity, reactions were performed at various $\mathrm{pH}$ but optimum activity was found at $\mathrm{pH} 9.0$ for Elizabethkingia meningoseptica KB042 isolated from chicken feathers by Nagal et al., ${ }^{25}$.

\section{Effect of Temperature on Activity of Enzyme}

Protease: Influence of temperature on Bacillus sp. EW-2 protease activity was observed by incubating the enzyme at different temperature ranging from $35-100{ }^{\circ} \mathrm{C}$ and residual activity were determined under enzyme assay condition. The optimum activity of enzyme was taken as $100 \%$. The temperature profile of protease activity of Bacillus sp. EW-2 were showed maximal enzymatic activity 
of (52 Units $/ \mathrm{ml})$ at $80{ }^{\circ} \mathrm{C}$, which indicated that the enzyme was thermostable at high temperature. The protease retained more than $50 \%$ of the highest activity between $40-70{ }^{\circ} \mathrm{C}$. Subsequently, the enzyme activity progressively decreased at $100{ }^{\circ} \mathrm{C}$. In our study, although the bacterium was able to grow well at temperature up to $50{ }^{\circ} \mathrm{C}$, but it preferred thermophilic range of temperature for optimum activity at $80{ }^{\circ} \mathrm{C}(52 \mathrm{U} / \mathrm{ml})$. The protease from Bacillus sp P2 was isolated and produce the thermostable protease and optimum activity was found at $90{ }^{\circ} \mathrm{C}^{26}$.

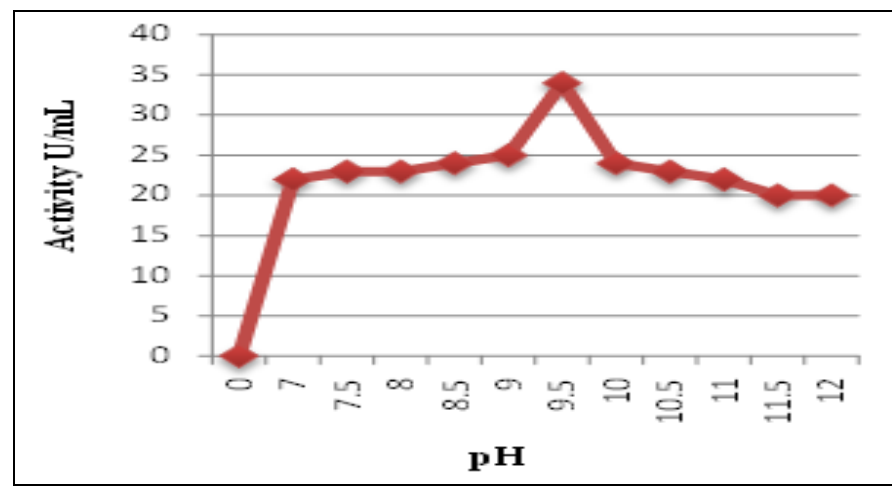

FIG. 1: EFFECT OF pH ON PROTEASE

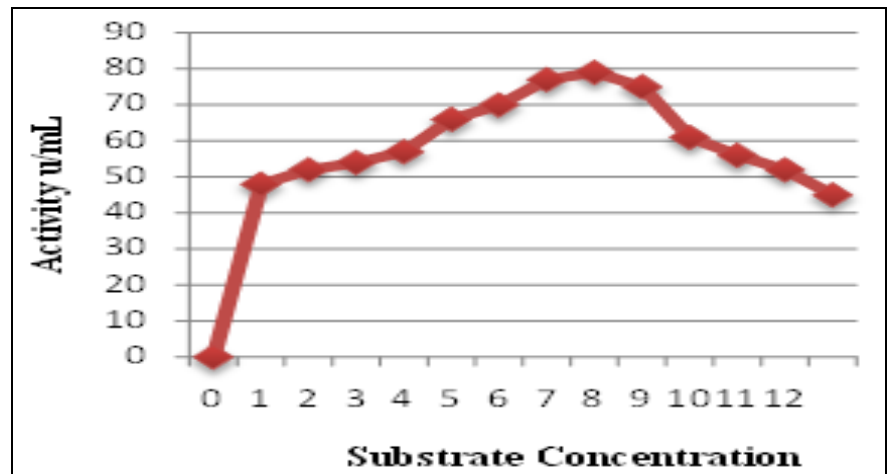

FIG. 3: EFFECT OF SUBSTRATE CONCENTRATION

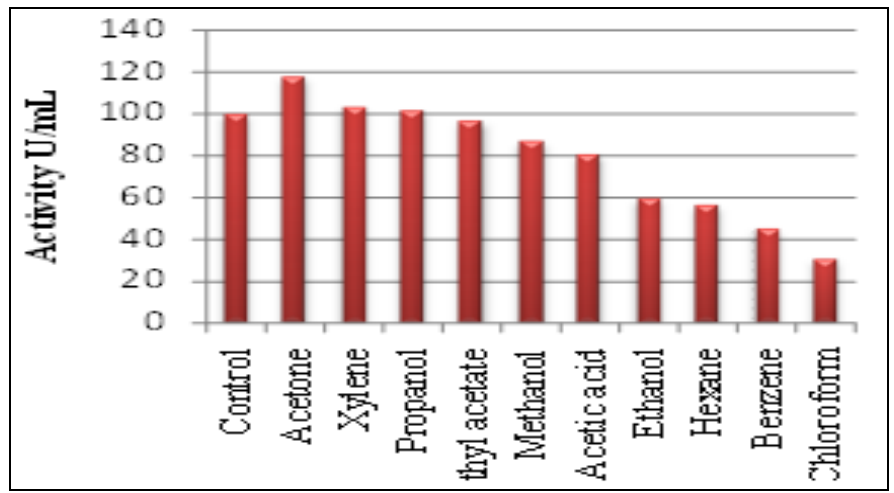

FIG. 5: EFFECT OF ORGANIC SOLVENTS ON PROTEASE

Effect of Substrate Concentration on Activity of Enzyme Protease: The influence of different concentrations of substrate was assayed ranging from 1 - $12 \mathrm{ml}$ under constant assay conditions. The maximum enzymatic activity (80 Units $/ \mathrm{ml})$ at $4 \mathrm{ml}$ of substrate concentration was considered as $100 \%$. However, the activity was dramatically decreased as the substrate concentration increases more than $8 \mathrm{ml}$.

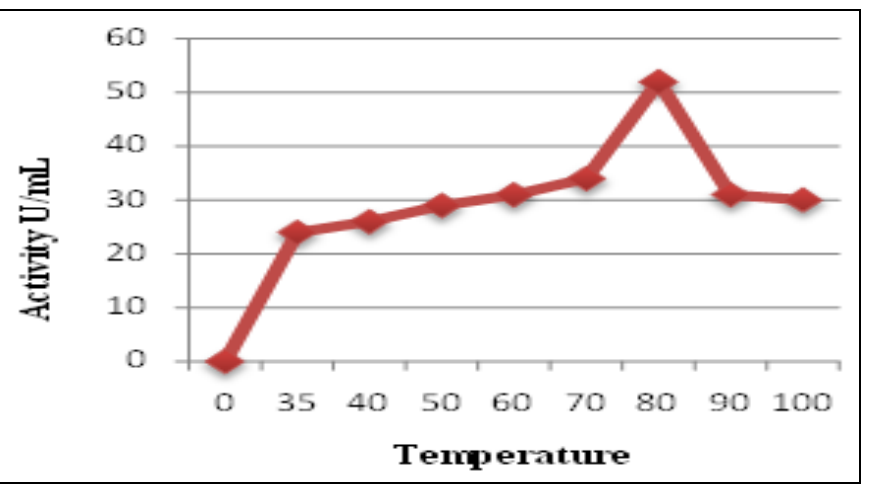

FIG. 2: EFFECT OF TEMPERATURE ON PROTEASE

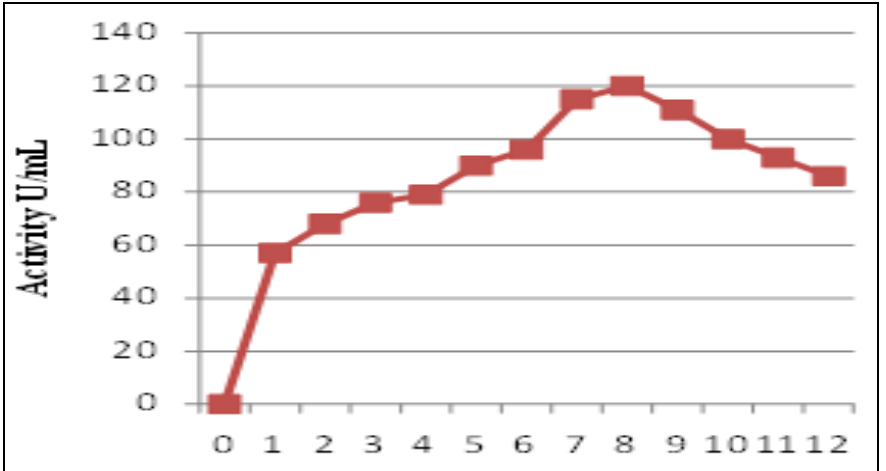

FIG. 4: EFFECT OF ENZYME CONCENTRATION ON PROTEASE

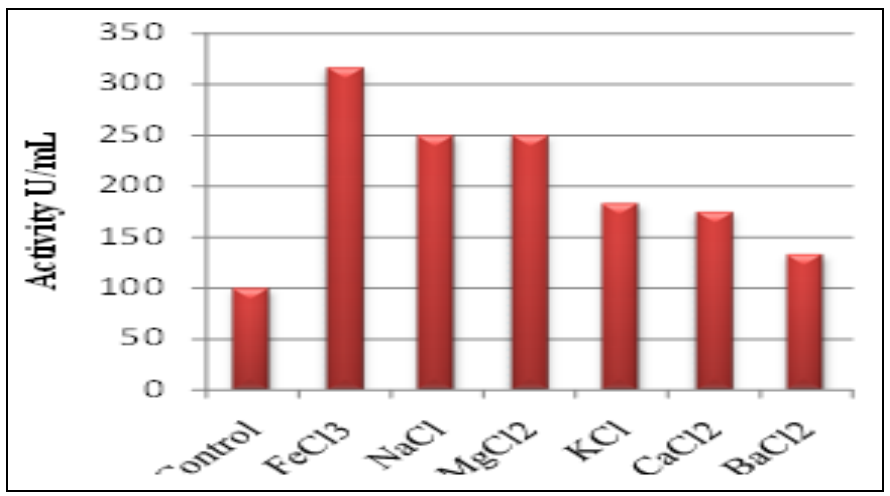

FIG. 6: EFFECT OF METAL IONS ON PROTEASE

Effect of Enzyme Concentration on Activity of Enzyme Protease: The effects of different enzyme concentrations ranging from $1-12 \mathrm{ml}$ was carried out under assay conditions. The enzyme shows maximum enzymatic activity (120 Units $/ \mathrm{ml})$ at 8 $\mathrm{ml}$ of enzyme concentration and it was considered as $100 \%$. The activity of protease decreases as the enzyme concentration increases more than $9 \mathrm{ml}$. 
Influence of Different Metal Ions on Activity of Enzyme Protease: The influence of different metal ions on activity of Bacillus sp. EW-2 protease was carried out under the assay conditions. Metal ions have different effects on activity of protease. The enzyme activity without any additives was taken as $100 \%$. The enzyme activity was enhanced by $\mathrm{KCl}$, $\mathrm{NaCl}, \mathrm{FeCl}_{3}, \mathrm{BaCl}_{2}, \mathrm{CaCl}_{2}$ and $\mathrm{MgCl}_{2}$. The optimum protease activity (316.67\%) was enhanced in presence of $\mathrm{FeCl}_{3}$.

Influence of Various Organic Solvents on Activity of Enzyme Protease: The effect of organic solvents on the activity of Bacillus sp. EW2 protease was determined. Organic solvents have different effects on activity of protease. The enzyme activity without any additives was taken as $100 \%$. The enzyme activity was enhanced only by Acetone. However, the protease activity was inhibited by ethanol, methanol, chloroform, benzene, hexane, ethyl acetate and acetic acid.

CONCLUSION: The Bacillus pumilus EW-2 strain isolated and extracellular synthesis of thermostable alkaline metalloprotease. Effects of metal ions and enhance the activity indicated that the alkaline protease belongs to the family of serine proteases. The optimum temperature at $80{ }^{\circ} \mathrm{C}$ and $\mathrm{pH} 9.5$ for protease activity thereby give an opportunity to its biotechnological potential and to take super advantage in leather, detergent and pharmaceuticals industries as an eco-friendly.

\section{ACKNOWLEDGEMENT: Nil}

CONFLICT OF INTEREST: Author has no conflict of interest.

\section{REFERENCES:}

1. Hameş-Kocabaş EE and Uzel A: Alkaline protease production by an actinomycete MA1-1 isolated from marine sediments. Annals Microbiol. 2007; 57(1): 71-75.

2. Dhundale VR, Nagarkar RD, More VR and Hemke VM: Partial characterization and optimization of alkaline amylase production from Bacillus lehensis isolated from alkaline saline Lonar lake. Int. J.Advn. Biotech. Res. 2014; 53: 1531-1536.

3. Gençkal $\mathrm{H}$ and Tari C: Alkaline protease production from alkalophilic Bacillus sp. isolated from natural habitats. Enz. Microbial Technol. 2006; 39(4): 703-710.

4. Kumar D and Bhalla TC: Microbial proteases in peptide synthesis: approaches and applications. Appl. Microbial. Biotechnol.2005; 68(6): 726-736.

5. Van den Burg B: Extremophiles as a source for novel enzymes. Curr. Opin. Microbiol. 2003; 6: 213-218.
6. Ates O, Oner TE, Arikan B, Denizcl AA and Kazani D: Isolation and identification of alkaline protease producer halotolerant. Bacillus licheniformis strain BA17. Annals of Microbiol. 2007; 57 (3): 369-375.

7. Patel R, Dodia M and Singh SP: Extracellular alkaline protease from a newly isolated haloalkaliphilic Bacillus sp. Production and optimization. Proc. Biochem. 2005; 40: 3569-3575.

8. Grant WD and Tindall BJ: The isolation of alkalophilic bacteria. In: Gould GW, Corry ICL (Eds.) Microbial Growth and Survival in Extremes of Environment. Academic Press, London, 1980; 27 -36

9. Jones BE, Grant WD, Duckworth AW and Owenson GG: Microbial diversity of Soda lakes. Extremophiles.1998; 2: 191-200.

10. Chaphalakar S and Dey S: Some aspects of production of extracellular protease from Streptomyces diastaticus. J. of Micro. Biotechnol. 1994; 9: 85- 100.

11. Joshi AA, Kanekar PP, Kelkar AS, Shouche YS, Vani AA, Borgave SB and Sarnaik SS: Cultivable bacterial diversity of alkaline Lonar lake, India. Microbial Ecology. 2008; 55(2): 163-172.

12. Surakashi VP, Antony CP, Sharma S, Patole MS and Shouche YS: Temporal bacterial diversity and detection of putative methanotrophs in surface mats of Lonar crater lake. J. of Basic Microbiol. 2010; 50: 465-474.

13. Tambekar DH and Dhundale VR: Studies on the physiological and cultural diversity of bacilli characterized from Lonar lake (MS) India. Biosci Discov. 2012; 3(1): 34-39

14. Dhundale VR, More VR, Nagarkar RD, Hemke VM and Tambekar DH: Isolation and characterization of a novel amylase from Bacillus pseudofirmus DW4 (1). Indian J Life Science. 2014; 4(1): 69-76.

15. Hemke VM, Joshi SS, Fule NB, Dhundale VR and Tambekar DH: Phenetic diversity of alkaliphilic protease producing bacteria from alkaliphilic environment. Indian $\mathrm{J}$ Sci Res.2015; 10(1): 47-52.

16. Sambrook J, Fritsch EF and Maniatis T: Molecular cloning: a Laboratory Manual, Cold Spring Harbor, New York. Edition 2, 1989.

17. Ausubel FM, Brent R, Kingston RE, Moore DD, Seidman JG, Smith JA and Struhl, K: Short protocols in molecular biology. Wiley, New York, Edition 5, Vol. II, 1992.

18. Gessesse A and Gashe BA: Production of alkaline protease by an alkaliphilic bacteria isolated from an alkaline Soda lake. Biotechnology Letters.1997; 19(5): 479

19. Tambekar DH, Tambekar SD, Jadhav AS and Babhulkar $\mathrm{BV}$ : Isolation and partial characterization of protease from Bacillus halodurans (AJ302709) from alkaline Lonar lake. International Journal of Pharmaceutical Sciences and Research, 2016; 7(11): 4546.

20. Nielsen P, Fritze D and Priest FG: Phenetic diversity of alkaliphilic Bacillus strains: proposal for nine new species. Microbiology.1995; 141: 1745-1761.

21. Olivera N, Sequeiros C, Siñeriz F and Breccia JD: Characterization of alkaline proteases from a novel alkalitolerant bacterium Bacillus patagoniensis. World J. Microbiol Biotechnol, 2006; 22(7): 737-743.

22. Dhundale VR and Hemke VM: Phylogenetic analysis of Bacilli from haloalkaline Lonar Soda crater. Int J Pharm Bio Sci 2015; 6(4): (B) 27 -290.

23. Kumar CG and Takagi H: Microbial alkaline protease; from a bio industrial view point. Biotechnol Adv.1999; 17: 561-594.

24. Sookkheo B, Sinchaikul S, Phutrakul S and Chen ST: Purification and characterization of the highly 
thermostable proteases from Bacillus stearothermophilus TLS33. Prot. Exp. Pur. 2000; 20: 142-151.

25. Nagal S, Kango N and Jain PC: Production of alkaline protease from Elizabethkingia meningoseptica KB042 using chicken feathers. Annals of microbiology. 2010; 60(4): 629-635.
26. Kaur S, Vohra RM, Kapoor M, Beg QK and Hoondal GS: Enhanced production and characterization of a highly thermostable alkaline protease from Bacillus sp. P-2. World J. Microbiol Biotechnol.2001; 17(2): 125-129.

\section{How to cite this article:}

Hemke VM and Dhundale VR: Characterization and stability of extracellular alkaline proteases from halophilic and alkaliphilic bacteria isolated from saline habitat of Lonar soda lake, India. Int J Pharm Sci \& Res 2018; 9(5): 1974-79. doi: 10.13040/IJPSR.0975-8232.9(5).1974-79.

All @ 2013 are reserved by International Journal of Pharmaceutical Sciences and Research. This Journal licensed under a Creative Commons Attribution-NonCommercial-ShareAlike 3.0 Unported License.

This article can be downloaded to ANDROID OS based mobile. Scan QR Code using Code/Bar Scanner from your mobile. (Scanners are available on Google Playstore) 